TERRA. Revista de Desarrollo Local

e-ISSN: 2386-9968

Número 9 (2021), 80-102

DOI 10.7203/terra.9.22076

IIDL - Instituto Interuniversitario de Desarrollo Local

\title{
Identity, memory and rural development: public art in Fuendetodos (Zaragoza, Spain)
}

\author{
Guillermo Juberías Gracia \\ Departamento de Historia del Arte. Universidad de Zaragoza \\ guillermojuberias@unizar.es \\ https://orcid.org/0000-0003-0098-5287
}

Natalia Juan García

Departamento de Historia del Arte. Universidad de Zaragoza

natajuan@unizar.es

https://orcid.org/0000-0002-2506-6503

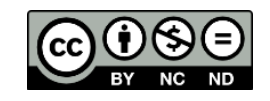

Esta obra se distribuye con la licencia Creative Commons

Reconocimiento-No Comercial-Sin Obra Derivada 4.0 Internacional 


\title{
SECCIÓN ARTÍCULOS
}

\author{
Identidad, memoria y desarrollo rural: arte público en Fuendetodos (Zaragoza, España)
}

Resumen: Las pequeñas ciudades de las zonas despobladas de España buscan actualmente formas de promocionar su patrimonio cultural en su intento de crear riqueza. El pueblo natal de Francisco de Goya (Fuendetodos, en la región de Zaragoza, España) alberga un importante conjunto de arte público que no ha sido analizado hasta ahora. Nuestro propósito es examinar la evolución histórica del arte público en esta localidad desde la erección del Monumento a Goya del artista Julio Antonio en 1920 (un hito importante en la historia del arte público español) hasta la creación del Goya Street Art Museum, un museo de arte urbano al aire libre que se extiende por todo el pueblo. Nuestro trabajo de investigación se basa en material periodístico, así como en documentación de archivo y fotografías, para dar cuenta de la historia de los monumentos y murales urbanos de Fuendetodos. El análisis del trabajo de campo realizado in situ revela el potencial de este pueblo, ya que su colección de arte contemporáneo al aire libre puede servir para revitalizar la zona y ayudar en la lucha contra la despoblación.

Palabras clave: Territorio, patrimonio, revitalización, monumento, espacio público, Goya.

\section{Identity, memory and rural development: public art in Fuendetodos (Zaragoza, Spain)}

Abstract: Small towns in Spain's depopulated areas are currently seeking ways to promote their cultural heritage in their bid to create wealth. Francisco de Goya's birthplace (Fuendetodos in the region of Zaragoza, Spain) holds a significant ensemble of public art which has not been analysed up to now. It is our purpose to examine the historical evolution of public art in this town from the erection of the Monumento a Goya by artist Julio Antonio in 1920 (a major landmark in the history of Spain's public art) to the creation of the Goya Street Art Museum, an open-air urban art museum that extends throughout the village. Our research work is based on newspaper and periodical material as well as archive documentation and photographs in order to render an accurate account of the history of Fuendetodos' urban monuments and murals. The analysis of the fieldwork carried out in situ reveals the potential of this town as its collection of open-air contemporary art may serve to revitalize the area and assist in the struggle against depopulation.

Key words: Territory, heritage, revitalizing, monument, public space, Goya.

Recibido: 02 de diciembre de 2021

Devuelto para revisión: 09 de diciembre de 2021

Aceptado: 13 de diciembre de 2021

\section{Referencia / Citation:}

Juberías, G., y Juan, N. (2021). Identity, memory and rural development: public art in Fuendetodos (Zaragoza, Spain). TERRA. Revista de Desarrollo Local, (9), 80-102. DOI 10.7203/terra.9.22076 
1. El patrimonio cultural es un motor del desarrollo turístico en territorios despoblados como Aragón.

2. Fuendetodos alberga un importante conjunto de arte público que no ha sido todavía investigado.

3. Estudiar la historia y evolución del arte público en Fuendetodos permite su correcta difusión.

4. Escultura, instalación y pintura mural son las principales modalidades de arte público en la localidad.

5. La calidad de las obras y el renombre de sus autores constituyen un atractivo turístico.
1. Cultural heritage is a driving force for tourism development in depopulated areas such as Aragon.

2. Fuendetodos is home to an important body of public art that has not yet been investigated.

3. Studying the history and evolution of public art in Fuendetodos allows its correct dissemination.

4. Sculpture, installation and mural painting are the main forms of public art in the town.

5. The quality of the works and the renown of their authors constitute a tourist attraction.
1. El patrimoni cultural es un motor del desenvolupament turistic en territoris despoblats com Aragó

2. Fuendetodos acull un important conjunt d'art públic que no ha estat investigat.

3. Estudiar la història $i$ l'evolució de l'art públic en Fuendetodos permet la seua correcta difusió.

4. Escultura, instal·lació i pintura mural són les principals modalitats d'art públic en el municipi.

5. La qualitat de les obres i el renom dels seus autors constitueixen un atractiu turístic. 


\section{INTRODUCTION AND BACKGROUND}

Our analysis takes into account the existence of a largely unknown yet remarkable collection of public art in Fuendetodos that could actually serve as an asset to revitalize the area of Campo de Belchite, currently suffering the full impact of depopulation. Fuendetodos has fewer than 150 registered inhabitants (INE, 2020) only half of whom live there permanently. There is no school or bakery and the Covid-19 pandemic has further diminished the amount of tourists who used to visit the village (Cruz, 2019). Appropriate management of its cultural heritage could contribute to boosting tourism in the area.

The promotion of cultural heritage in order to revitalize a territory demands previous and exhaustive research work. In this particular case, our work focused not only on the historical-artistic analysis of the various urban interventions but also on the social impact they had on the locality ${ }^{1}$. The central matter of our paper therefore consists of examining the historical process of public art and its evolution and interrelation with the local population in order to establish the potential role this heritage may play in the revitalization of the area. This research work is key to understanding the emergence and evolution of public art in Fuendetodos from the early twentieth century to the present day, a period that features especially low population density. Thus, the first question we address is: what was the process of creation of the collection of public art in Fuendetodos? We then explore how public art (in the form of sculptures, installations and mural paintings) contributed to the creation of a local identity based around the figure of Francisco de Goya. The third question we attempt to ascertain is how the urban heritage of the locality may serve to revitalize it in social, cultural and economic terms.

\section{THEORETICAL-CONCEPTUAL BACKGROUND: DEPOPULATION AND THE ROLE OF PUBLIC ART IN REVITALIZING THE TERRITORY}

The concept of España Vaciada-hollowed-out Spain-gained force both in the media and academia especially after the publication of La España vacía (2016) by writer and journalist Sergio del Molino and of his essay Contra la España vacía (2021). He reflects on the phenomenon of rural exodus which reached its peak between the 1950's and 1970's but whose effects particularly hit some regions in Spain in the last decade resulting in extremely low population density in those areas. While these publications may have had great repercussions, the fact is that the question has been analysed and examined for decades. Scholars such as Luis Antonio Sáez considers that the source of this alarming situation:

(...) en la mayor parte de los territorios españoles, y Aragón es el paradigma, es consecuencia de procesos emigratorios muy intensos en la etapa de crecimiento más intenso, década de los sesenta y primera mitad de los setenta, y de la escasa capacidad regenerativa actual, tanto por la baja tasa

\footnotetext{
1 The authors of this paper are members of the Observatorio Aragonés de Arte en la Esfera Pública (OAAEP) - funded by the Government of Aragon through FEDER - whose director is Dr. Jesús Pedro Lorente Lorente, professor of the Department of the History of Art of the University of Zaragoza. The members of OAAEP study public art in streets, squares, parks, open-air locations, museums, galleries and virtual spaces on the Internet and social networks. See https://oaaep.unizar.es/
} 
de natalidad como por las escasas mujeres en edad fértil que todavía residen en esas áreas de baja densidad (Sáez, 2003, p. 131).

(...) in most of Spain's regions, Aragon is the paradigm, results from highly intense migratory processes during the period of greatest economic growth - the 1960's and first half of the 1970'sand from the currently limited regeneration capacity both due to low birth-rate and to the scarcity of fertile women who still live in low-populated areas (Sáez, 2003, p. 131).

Most of the inhabitants of Aragon, the fourth largest region in Spain, live in the capital city, Zaragoza ${ }^{2}$. Its surrounding area, however, does not escape depopulation: the region of Campo de Belchite - where Fuendetodos is located - has a population density below five inhabitants per square kilometre. In human geography this fact is referred to as a demographic desert: a territory with fewer than 10 inhabitants per square kilometre. This phenomenon, far from being endemic to Spain, constitutes one of Europe's greatest challenges and is particularly serious in Portugal, Greece, Italy and Germany. As the great European capital cities grow, rural areas become deserted. The unremitting migration to cities and demographic change - extremely low birth-rate and ageing populationinevitably lead to social fragmentation and unequal access to basic social services, education, work and leisure (Escribano, 2012; Romero y Escribano, 2013; Escribano y Vercher, 2018; Camarero y Oliva, 2019; Sáez 2019a, 2019b).

This issue, however, is far from new: in the early 20th-century Spain already underwent a serious crisis as most rural territories remained isolated and removed from modernization, maintaining archaic farming practises. Since the late 19th-century, however, scholars and experts of various disciplines had already voiced the pressing need to modernize rural areas, coining the term España Negra-Dark Spain-to refer to those isolated and impoverished regions (Bozal, 2020).

One of the best portrayers of Dark Spain was painter Ignacio Zuloaga. He and his group, which included many of the members of the so-called Generation of 1898, dreamed of a Spain where culture would shed light on backwardness (Suárez-Zuloaga, 2020). Thanks to Zuloaga's determination Fuendetodos - up until then a small village of just onethousand inhabitants in the early 20th-century-experienced a cultural renaissance as it was revisited as Goya's hometown and as an art beacon to contemporary culture. The currently operating museum of etchings, the house of Goya's birth and the adjacent exhibition hall set in the building where the old school stood, gifted to the village by Zuloaga, constitute vestiges of the intense cultural activity deployed in Fuendetodos in the early 20th-century. From 1968 to 1981 the aforementioned exhibition hall hosted the Museum of Goya, dedicated to contemporary art and erected thanks to donations contributed by renowned Spanish artists in the second half of the 20th-century, as analysed by Pedro-Lorente and Picazo (2003).

The work of professor Jesús Pedro Lorente was taken into account in the analysis of art aspects, paying particular attention to his book Arte público en Aragón. Nuestro patrimonio colectivo al aire libre (2016) which provides an overview of the various types of public art in the region. Reference is made to the Monumento a Goya by Julio Antonio (1920) and the concept of public art is limited to focusing on publicly owned artworks displayed in the open air. This served as the framework for this paper on Fuendetodos

\footnotetext{
${ }^{2}$ Aragon, particularly hit by depopulation, carried out innovative research work on the consequences of low population density in some areas. Particularly noteworthy are the analyses produced by the Centro de Estudios sobre la Despoblación y Desarrollo de Áreas Rurales (CEDDAR), within the Rolde de Estudios Aragoneses.
} 
which does not contemplate private artworks whose display in the open air depends on the willingness of the owner. We also used as a reference the research conducted by Jesús Pedro Lorente on the presence of public art on the Internet (2008 and 2009).

Finally, despite the lack of research work concerning the potential of public art in tourist growth in rural areas, the guidelines produced by professor Remesar (2007) on the role of public art in urban regeneration processes also served as a reference. Furthermore, concerning the use of public art as a tool to revitalize scarcely populated areas, we examine the instances of other localities in Aragon recently analysed during the Jornadas Internacionales de Políticas Patrimoniales: Cultura, Territorio y Patrimonio, organized by the research team Observatorio Aragonés de Arte en la Esfera Pública. The analysis of public art in the town of Hecho (Huesca) presented by professors Prieto and Ruiz (2021) was particularly noteworthy.

\section{OBJETIVES, METHODOLOGY AND CASE STUDIES}

Taking into consideration the aforementioned conceptual bases, this paper has two main objectives. First, to analyse from a historical-artistic viewpoint the complex collection of public artworks in Fuendetodos. To this end, the local public art heritage was studied paying detailed attention to all the artworks, from the Monumento a Goya displayed in the square where the church is situated to the latest murals painted as part of the Goya Street Art Museum, a project created in 2017 which to date continues to make a vibrant contribution to the public space.

To reach this goal, the methodology used is grounded on the four main pillars of historical-artistic investigation. The first step consisted of a comprehensive scrutiny of bibliography regarding the subject matter. Secondly, the various documental sources found in regional and national archives, both private and public, were analysed. Historical hemerographic files proved extremely useful because of the abundant data they contributed concerning the process of creation of public artworks. The third stage consisted of field work carried out in situ. Once all the data had been assembled, analysed, screened and contrasted, it was compiled and interpreted prior to drafting this paper.

The second objective is to establish how this collection of public art, with the leading figure of Goya, may act as a lever to change the forces at play in the town and its surrounding area. In order to analyse this question, previous studies of public art in Aragon were taken into consideration, comparing the situation of Fuendetodos to other places both inside and outside the region.

The cases studied consisted therefore of the various artworks that constitute the town's public art heritage: mainly public monuments and mural paintings which may be freely visited at any time of the year (Lorente, 2016).

\section{PUBLIC ART IN FUENDETODOS: FROM THE PUBLIC MONUMENT TO THE GOYA STREET ART MUSEUM}

The figure of Francisco de Goya is the main character of the numerous contributions to commemorate him in his hometown. In the following pages an analysis of the public artworks displayed in the streets of Fuendetodos is produced. 


\subsection{The monument by Julio Antonio (1916-1920)}

The first relevant instance of public art erected in Fuendetodos was the Monumento a Goya designed by the sculptor from Tarragona Julio Antonio (1889-1919). Due to his premature death this was one of the artist's last works of art (Figure 1).

Figure 1. Monumento a Goya, Julio Antonio (1916-1920). Plaza de las Reliquias, Fuendetodos

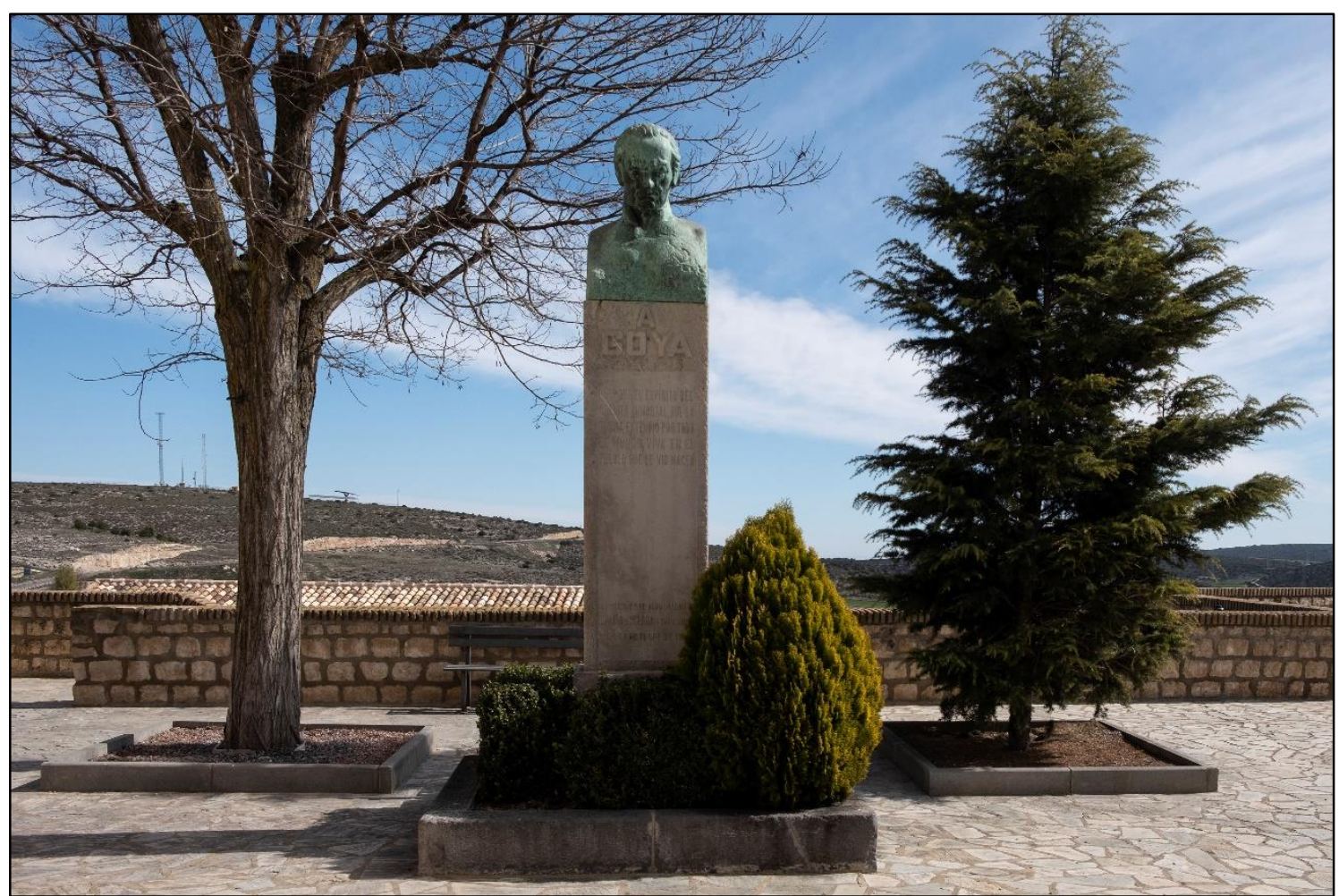

Photograph by the authors of the paper.

This artwork must be set against the backdrop of the Aragonesismo, a movement to bolster regional identity that gained strength in Aragon in the early 20th-century. Regenerationism had also intensified in this period, particularly after the Debacle of 1898. This political trend endorsed by politicians, writers and scholars from various disciplines strived to set the guidelines for national "regeneration". Aragonesismo and Regenerationism sometimes went hand in hand in the defence of some figures of Aragonese history who could serve as models for citizens. Francisco de Goya thus was set as a beacon for contemporary Aragonese artists and great interest was aroused concerning his background (Lozano, 2008).

Ignacio Zuloaga (1870-1945) was a leading expert on Goya's work and played a major part in the promotion of Fuendetodos launching pioneering initiatives to attract tourists. A festival dedicated to Goya took place in Fuendetodos in 1913. As professor Alberto Castán points out, the celebration included a ball and a raffle of artworks made by local artists. The goal was to raise funds to buy the house where Goya was born, a campaign that Zuloaga had started (Castán, 2016). The house was purchased in 1915. One year later, on the occasion of the exhibition "Zuloaga and the Aragonese artists" set at the Museo 
Provincial of Zaragoza, Zuloaga travelled once more to Fuendetodos to supervise the construction of the new local school next to Goya's birthplace (Castán, 2016). The school was inaugurated in September 1917 with a celebration attended by composer Manuel de Falla, Polish singer Aga Lahowska, Aragonese nationalist critic José Valenzuela la Rosa, painter Pablo Uranga, some of Goya's descendants and the sculptor Julio Antonio. On Zuloaga's initiative, the young sculptor had been chosen to create the first Monumento a Goya in the town, and the ceremony to mark the beginning of the project took place on his visit in 1917.

The elaboration process of this monument was lengthy and complex. Some of the sketches of Goya's bust envisaged by Julio Antonio are housed in the Museu d'Art Modern of Tarragona (MAMT) and in the Museo Nacional Centro de Arte Reina Sofía of Madrid (MNCARS). They reveal the steps followed by the sculptor in the creation of the statue. The sketches should be dated to 1916-1917, as at the ceremony held in September 1917 the artist revealed a sketch of the project (Anonymous, 1917). Two days earlier, the newspaper La Acción published a photograph of the proposed monument which included a slender pedestal (Anonymous, 1917).

Figure 2. Final model of the Monumento a Francisco de Goya, Julio Antonio (1916-1917)

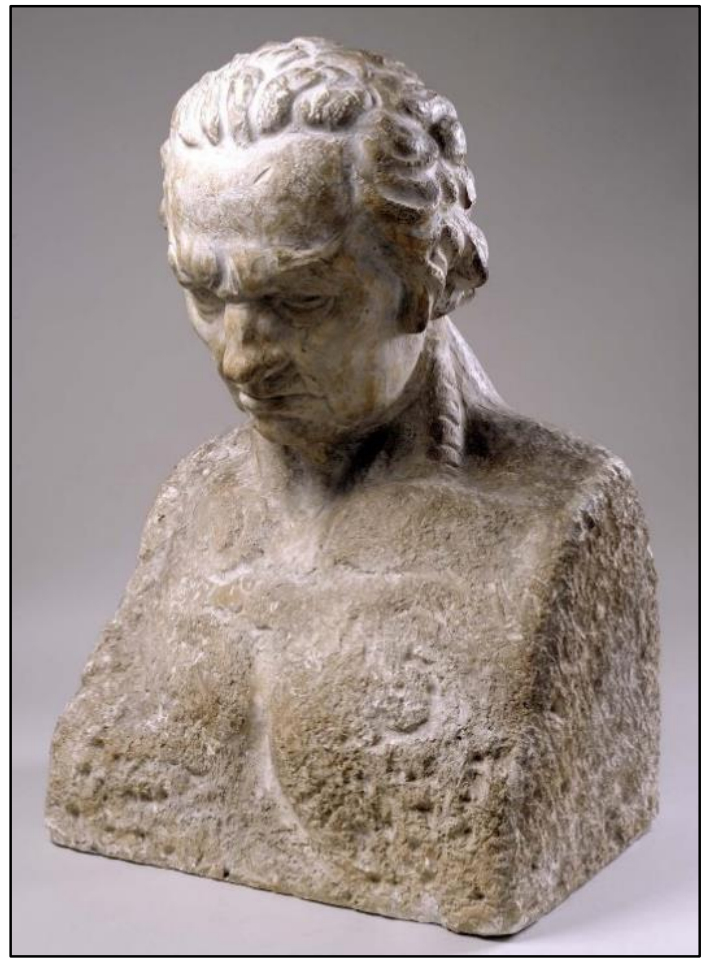

Photograph: Museo Nacional Centro de Arte Reina Sofía, Madrid.

Two phases may be differentiated in the process of creation of this monument. The first phase corresponds to Julio Antonio's work carried out in 1916 and 1917, a period when he made the sketches housed at the MAMT and MNCARS. The second phase, after the artist's death in 1919 consisted of the completion of the work by one of the sculptor's disciples, Enrique Lorenzo Salazar (1883-1928). Julio Antonio created a large initial model made of wood pulp $(95.5 \times 68 \times 45 \mathrm{~cm})^{3}$. He then made a plaster cast which is

\footnotetext{
${ }^{3}$ Museu d'Art Modern de Tarragona. Inventory number 3020.
} 
preserved at the MNCARS $(95,5 \times 63 \times 50 \mathrm{~cm})^{4}$. It shows a detailed finished head, with Goya's harsh glare looking down (Figure 2). The final bust for the monument of Fuendetodos was cast from this mould. The MAMT also houses several small casts, one without the pedestal and a larger one with a small plinth (Figure 3$)^{5}$.

Figure 3. Project of Goya's bust, Julio Antonio (1917)

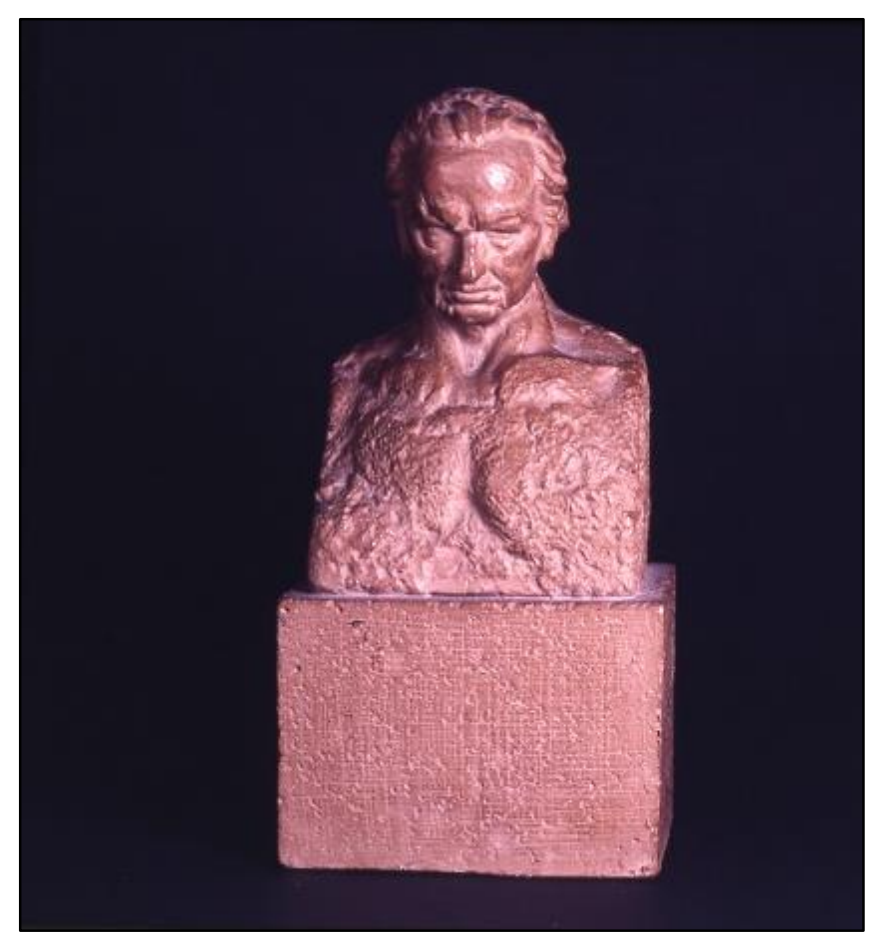

Photograph: Museu d'Art Modern de Tarragona.

The chosen spot to erect the monument was Plaza de las Reliquias, a square next to the church of Nuestra Señora de la Asunción. This vantage point, at the top of the town, yields a scenic view over Fuendetodos and its dry surrounding landscape. Moreover, the church housed the only painting by Goya kept in the village, the paintings on the doors of a reliquary cabinet and on the wall to which the cabinet was attached (Mena, 2015). A simple low ashlar wall was built around the monument. The photographs kept at the Archivo Histórico Provincial of Zaragoza (AHPZ) show that the wall looked much as it does nowadays.

The death of Julio Antonio at the age of 30 in February 1919 halted the already advanced process of creation of the monument. It was resumed by the aforementioned sculptor, Salazar (Correa, 1920). Art critic Emilio Ostalé Tudela corroborated Salazar's participation in the creation of the monument in an article published by the Catalan Journal La Hormiga de Oro in December 1925 (Ostalé, 1925) including a photograph by Francisco Samperio showing the inhabitants of the village gathered around the monument with the arid mountains that surround Fuendetodos in the background.

\footnotetext{
${ }^{4}$ Museo Nacional Centro de Arte Reina Sofía. Inventory number AD02514.

${ }^{5}$ The size of these respective casts is: $28 \times 15 \times 11 \mathrm{~cm}$ and $35 \times 17.5 \times 13 \mathrm{~cm}$. Inventory number: 3281 and 3295 .
} 
Zuloaga closely followed Salazar's work judging by the correspondence kept in the Archivo de la Fundación Zuloaga (Zumaya). On 29 August 1920 the sculptor sent to Zuloaga the plans of the monument and photographs of the sketches for the latter to comment on ${ }^{6}$.

The sculptor intended to use black stone for the pedestal and golden bronze for the head (García de Carpi, 1985), though eventually unpolished bluish jasper from the quarry of nearby Codos was used instead (Escar, 1926). Nowadays, wind erosion plus the discoloration caused by the passing of time have balanced the chromatic look of the monument providing a light blue-greenish patina (Figure 4).

Figure 4. Monumento a Goya (detail), Julio Antonio (1916-1920). Plaza de las Reliquias, Fuendetodos

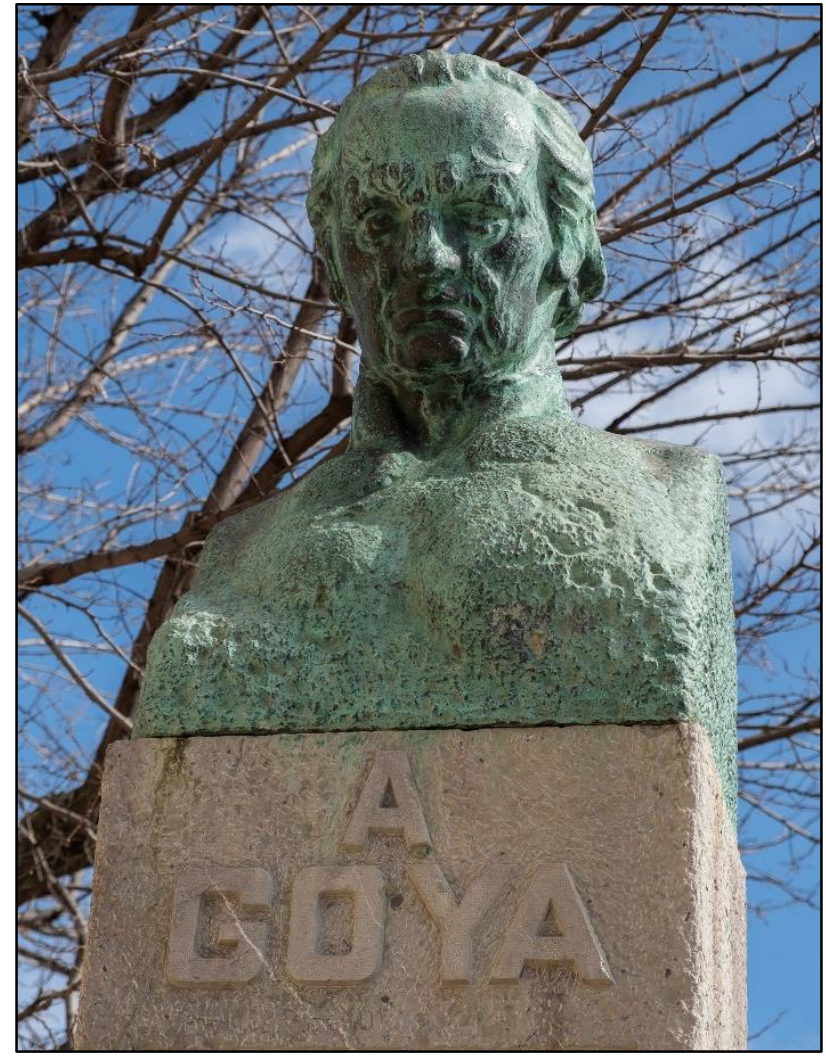

Photograph by the authors of the paper.

Antonio Salcedo commended the high quality of this simple monument, a unique instance in Julio Antonio's work because of its use of light and shadows and its faded contours redolent of Rodin, with whom Zuloaga had a close relationship (Salcedo, 1997).

The official inauguration of the monument took place one and a half years after the death of Julio Antonio, on 19 October 1920, with the attendance of Ignacio Zuloaga and some of his artist friends as reported by the local and national press (Anonymous, 1920). As a memento of the inauguration, the monument bears the inscription: "Erigen este monumento Ignacio Zuloaga y sus amigos. 19 octubre de 1920"_ "This monument was erected by Ignacio Zuloaga and his friends. 19 October 1920". The unofficial event, as

\footnotetext{
${ }^{6}$ Archive of Fundación Zuloaga [AFZ], Correspondence between Enrique Lorenzo Salazar and Ignacio Zuloaga, 1361, (Madrid, 29-VIII-1920).
} 
Emilio Ostalé Tudela reports, was completed with a mass in memory of both Goya and Julio Antonio and was attended by Zuloaga and artists and admirers of the painter (Ostalé, 1928).

The Sindicato de Iniciativa y Propaganda de Aragón (SIPA) played a crucial role in the early promotion of Fuendetodos as a tourist destination. This association, officially incorporated in 1925 though created previously, brought together members of Zaragoza's commercial middle-class. These types of unions were very active in the promotion of Spain as a tourist destination in the first third of the 20th century. Despite their limited funding and local scope - they were created with the purpose of promoting tourism in a particular city or region (Luque y Pellejero, 2009) - they published journals, organized trips and in the case of the SIPA, acted as travel agents for the city of Zaragoza. In May 1925, the SIPA organized a trip to Fuendetodos where scholars Joaquín Gimeno Riera and Manuel Abizanda gave speeches beside the Monumento a Goya in praise of the artist's hometown and applauded the initiatives undertaken by the union to promote cultural activities (Anonymous, 1925). A few months later, the November 1925 issue of the journal Aragón, edited by the SIPA, published an article about Goya written by researcher José Valenzuela la Rosa at the request of Ignacio Zuloaga dedicated to the children of the school of Fuendetodos (Valenzuela, 1925). The article ended with an image by photographer Eduardo Cativiela of the monument of Goya in his hometown.

Cativiela's photograph and the laudatory text were used again in the issue that the journal Aragón dedicated to Goya on the occasion of the centenary of his death in April 1928. This issue published two photographs of the landscape surrounding Fuendetodos, a panoramic view of the village, a full image of the house where Goya was born next to the finished building of the school and a picturesque photograph of one of the village streets showing adults and children around a stall selling pottery (Marín, 1928).

Besides the journal Aragón, another valued source in the study of the activities promoted by the SIPA is its collection of photographs housed at the Historical Archive of the Province of Zaragoza. The union created a significant photographic archive that served to document the appearance of the village and its arid surroundings, the visits of tourists and the tributes paid to Goya around the monument made by Julio Antonio and bore witness to the economic growth of the village thanks to Ignacio Zuloaga's philanthropic drive. Particularly noteworthy to our analysis is the image titled Grupo de amigos de Zuloaga que contribuyeron en el monumento a Goya (Group of Zuloaga's friends who contributed to the monument to Goya). This stereoscopic view portrays a crowd gathered around the monument to Goya comprising of members of the union and locals. The dry mountains and a group of humble houses can be seen in the background (Figure 5) ${ }^{7}$.

The images attest to the popularity Fuendetodos had achieved by the 1930's, when tributes to Goya not only increased the village's renown but also improved the lives of its inhabitants with the construction of a school, the paving of the streets and the frequent trips organized to promote it as a tourist destination. The aforementioned article by Emilio Ostalé-Tudela in 1925 for the journal La Hormiga de Oro reports these improvements and the active part Ignacio Zuloaga played (Ostalé, 1925).

The monument, the first of a series of public artworks created in Fuendetodos in the ensuing decades, has remained in its original setting. This accentuated the use of the square as a gathering point that hosted the inauguration of the monument in 1920, the

7 AHPZ, Audiovisual documents, Historical Photographic Archive of SIPA, ref. ES/AHPZ MF/SIPA/_0475_021. 
speeches delivered during the visit of the SIPA in 1925 and, in March 2021, the official photograph of the commemoration of the 275th anniversary of Goya's birth in Fuendetodos (García, 2021).

Figure 5. Grupo de amigos de Zuloaga que contribuyeron en el monumento a Goya (1920's)

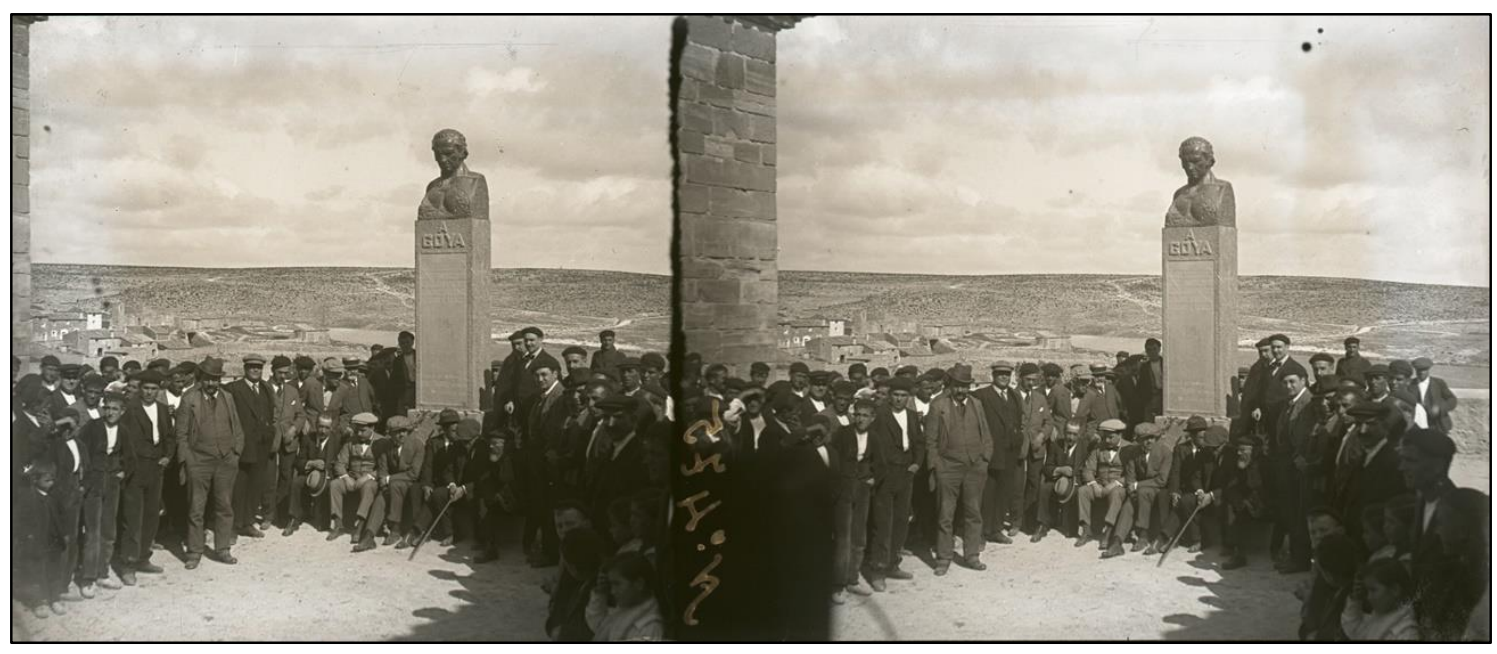

Historical Photographic Archive of SIPA, AHPZ.

\subsection{The bust by José Gonzalvo (1978)}

Indeed, anniversaries served to boost cultural initiatives in the village and the erection of more monuments added to Fuendetodos' public art heritage. Thus, on the occasion of the 150th anniversary of Goya's death, in April 1978, another bust was inaugurated and also set in a strategic position: opposite the artist's house availing of the slope between La Alfóndiga street where the house and school stand and Francisco de Goya street. The bust created by José Gonzalvo (1929-2010) is set on one of the walls overlooking Goya's birthplace. Gonzalvo's celebrated portrait uses the peculiar language of public sculpture in the 1970's, breaking the figure into geometrical shapes, harsher in the hair and clothes and subtler in the face. The bust, devised to be observed from the square below, rests on a small masonry pedestal as a continuation of the wall that raises it above Francisco de Goya street (Figure 6).

The bust is made of iron, José Gonzalvo's favourite material, which has a deep tradition in Spanish metalwork. Gonzalvo was greatly interested in reviving local craft techniques particularly after his participation at the World Fair of New York in 1964. After that event, the artist decided to settle in his hometown, Rubielos de Mora in Teruel. His steadfast commitment to the rural community is shown by the large amount of sculptures that he created for villages throughout Spain: Rubielos, Fuendetodos, Albentosa, Alcañiz, Calamocha, Bocairent, Alcoy, Benasal, etc. His firm link to rural Spain percolates his inaugural speech at the Real Academia de San Fernando (Madrid), titled "El artista y el pueblo" "The artist and the village" (De la Calle, 2013). His interest in the rural world did not mean rejecting the avant-garde influences he had received in his youth. The bust of Goya reveals the inspiration drawn from masters such as Gargallo, Julio González and Pablo Serrano. A few years later, in 1984, on commission from the Centro Aragonés de Barcelona he made another monument to Goya, this time for Barcelona. The artist is 
depicted standing next to one of the figures of his painting Los Fusilamientos (De Lecea et al., 2009).

Figure 6. Bust of Goya, José Gonzalvo (1978). Francisco de Goya street, Fuendetodos

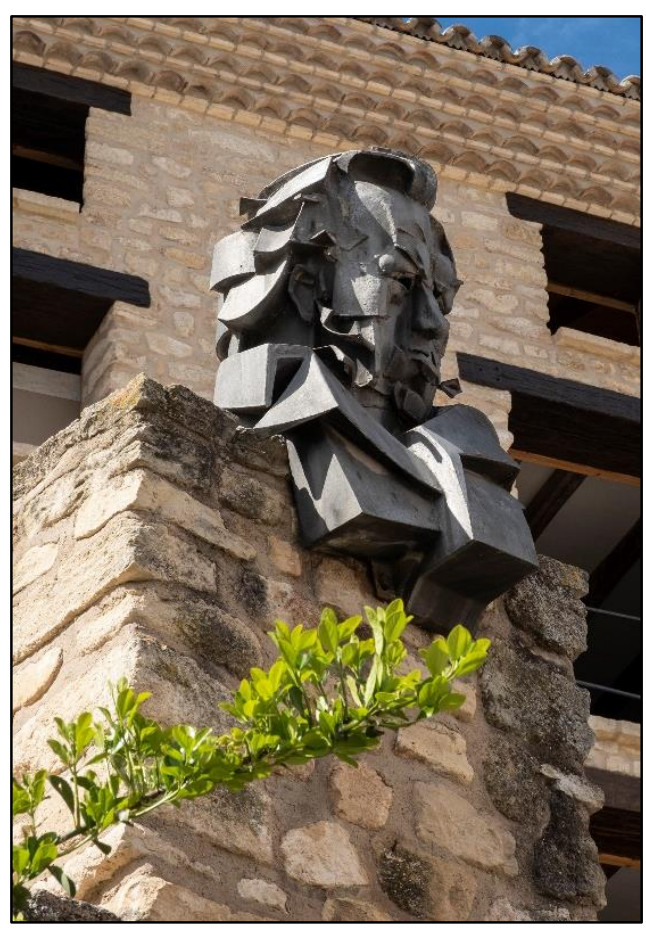

Photograph by the authors of the paper.

Figure 7. El Aquelarre, Yigal Tumarkin (1999). Fuendetodos

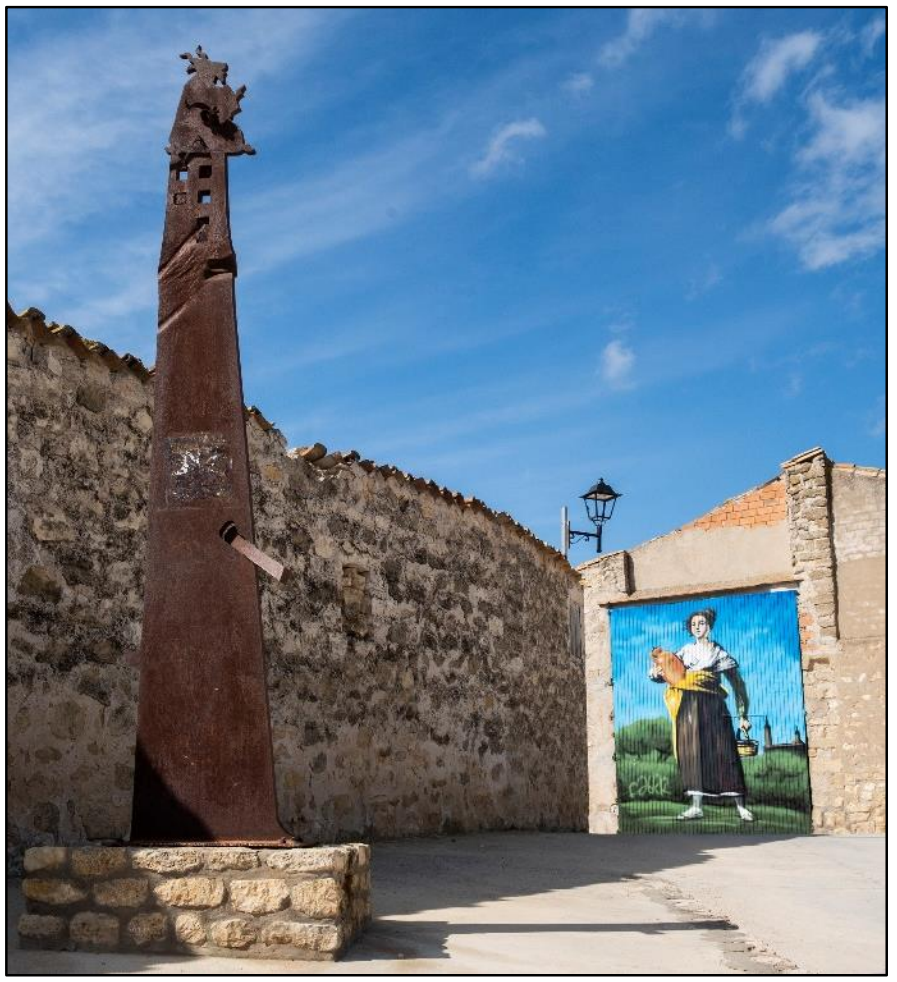

Photograph by the authors of the paper. 


\subsection{Aquelarre by Yigal Tumarkin (1999)}

Fuendetodos has also hosted the creations of foreign artists. The German artist of Israeli nationality Yigal Tumarkin (Dresden, 1933) created a corten steel sculpture titled Aquelarre in 1999. In his long career this sculptor trained at Ein Hod, an artist colony near Monte Carmelo, has created numerous sculptures for public spaces, especially throughout Israel. In Spain he made a corten steel sculpture for Pozoblanco (Córdoba) reproducing the silhouette of the soldier fatally shot in the head in Robert Capa's famous photograph The falling soldier (Fernández, 1989). This was the second version of the same figure he had already used in his monument Freedom is not Free (1986) for the city of Netanya in Israel. Adapting wild iconic figures to be set in highly different contexts is a constant feature of his creations. Thus, the figure of the male goat in Goya's Aquelarre, from his series of Black paintings stands not only in Fuendetodos but also in Abu Nabut park in Tel Aviv. The sculpture in Fuendetodos is simpler, consisting of an irregular vertical sculpture surmounted by a male goat where the author plays with the assembly of the figure and the void. The sculpture was initially set in a park in Fuendetodos but currently stands on a stone plinth next to a graffiti showing another of Goya's painting La Aguadora from the Museum of Fine Arts in Budapest (Figure 7).

\subsection{Goya Street Art Museum}

The Goya Street Art Museum (GSAM) constitutes a further instance of public art in Fuendetodos. In the last few years' street art museums have become widespread, displaying all types of artworks, at times in enclosed buildings or, as in the case of Fuendetodos, on walls and urban sites (Senserrich-Espuñes and García, 2019). The latter form of display of street art in the open air has become highly popular especially in South America, creating areas laden with stirring messages of protest and criticism against the establishment. In Fuendetodos the initiative was institutionally promoted by the local corporation through the Foundation Fuendetodos Goya with the collaboration of the Chamber of Commerce of Zaragoza. For this very reason, the conditions set in the rules of contest state that the subject matter of the murals may not promote content that infringes the law in any form ${ }^{8}$. The theme of the murals is also set: "Fuendetodos, its people, its traditions and its history". These matters have been tackled by the artists participating in the GSAM over the years. The first session, in 2017, attracted the highest number of artists with the participation of Xabier Anunzibai, Harsa, Treze, Isaac Mahow, Danjer and Álvaro Ortiz. The following year several doors and walls of the town were decorated with graffiti inspired by Goya's paintings. In 2019 the artist Faber took part and in 2020 Xolaka and Asier Vera.

As in the public monuments, the thread running through most of these interventions is the work of Francisco de Goya though some of the GSAM urban artworks break with stale references to Vicente López's portrait or the literal allusion to the Aragonese master. Thus, Álvaro Ortiz rendered a fresh vision of the image titled "A caza de dientes", from the series Los Caprichos. In this etching Goya made a witheringly scornful criticism of the superstition whereby some women would pull the teeth of a hanged person for their purported magical powers. Álvaro Ortiz reinterprets this topic painting a rural image with

8 The rules of the contest may be downloaded from the webpage of the Town Hall: http://ayuntamientofuendetodos.es/ (date of access: 24-IV-2021). 
zoomorphic creatures who drive tractors and uproot teeth from the earth. Modern techniques, the exploitation of the land and the labour referred-to by the artist through the bees involve new forms of a relinquishment of rationality (Figure 8).

Figure 8. A caza de dientes, Álvaro Ortiz (2017). Fuendetodos

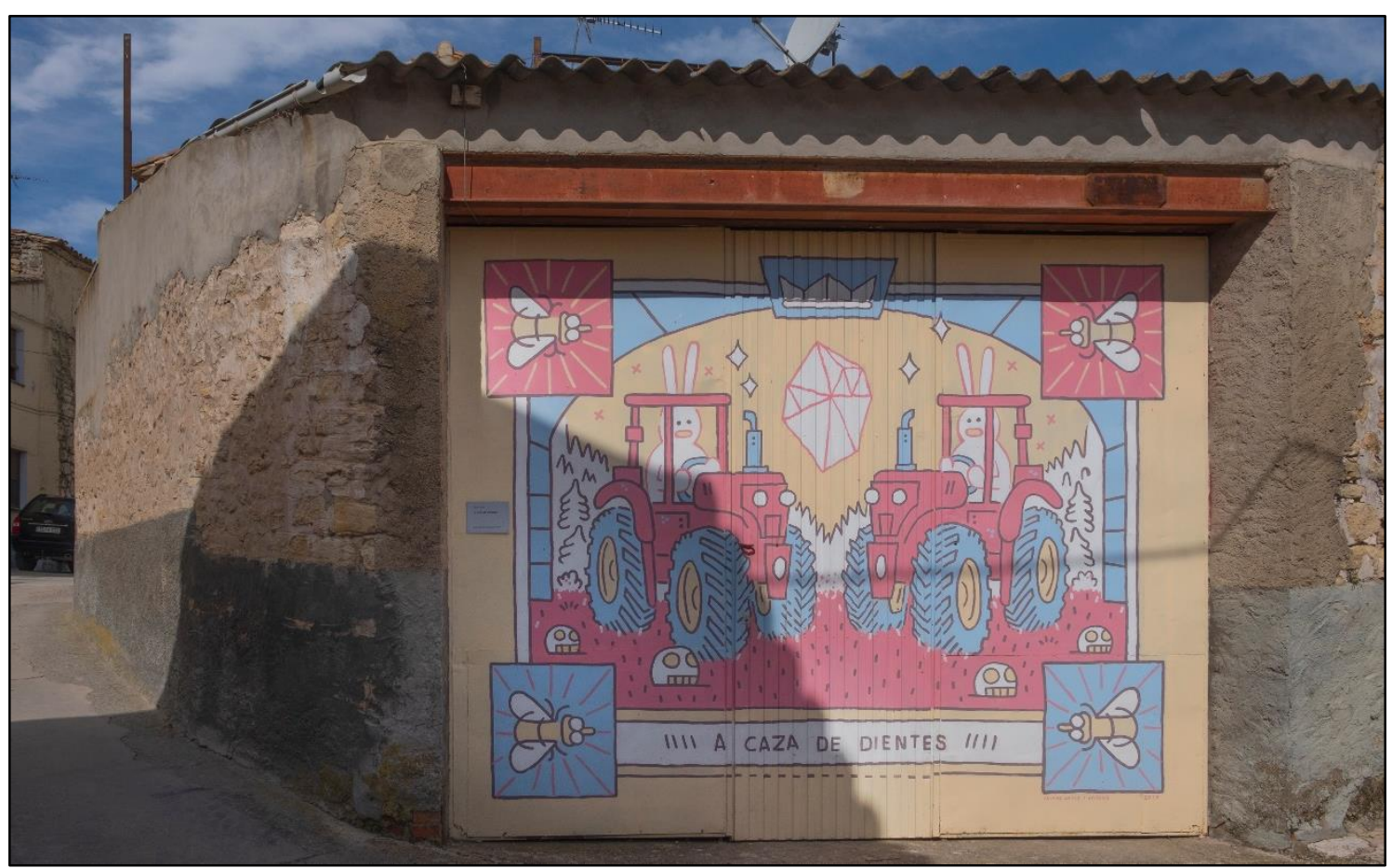

Photograph by the authors of the paper.

Figure 9. Agua, mano, vacío, Xabier Anunzibai (2017). Fuendetodos.

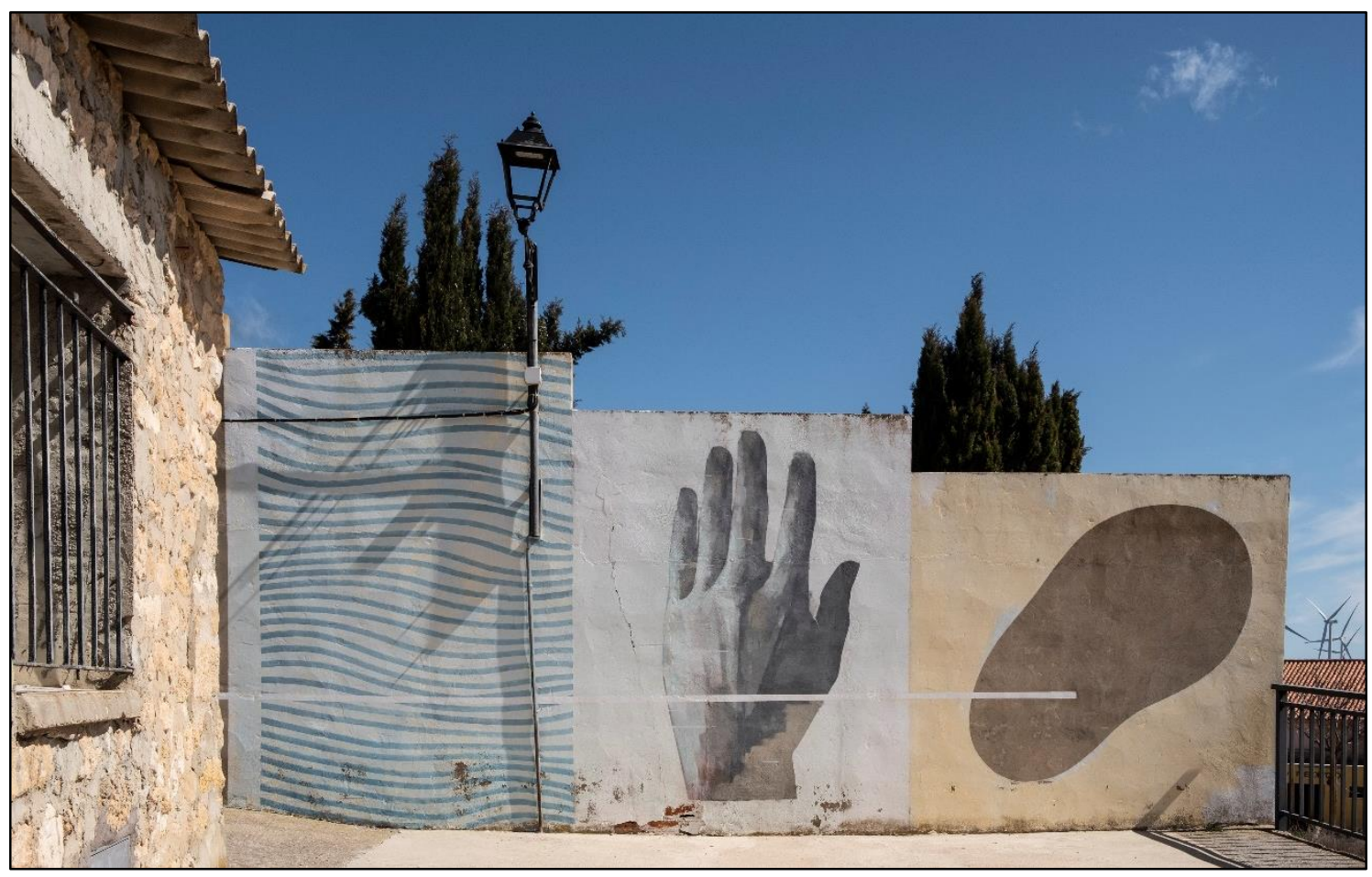

Photograph by the authors of the paper. 
On other occasions, the artists drop any reference to Goya in order to explore other aspects of local ethnography or etymology. Thus, Xabier Anunzibai delved into the topic of water, as the name of the village refers to the notion of a fountain. The artist uses a horizontal wall to produce a triptych that depicts water, the human hand that alters landscapes and the footprint that marks human influence on water and its surroundings. The chosen colours stress the arid landscape around Fuendetodos (Figure 9).

Arantxa Recio (Harsa) made an original intervention in the arch of San Roque a passageway linking two areas of Fuendetodos used by those walking from the church to Goya's birthplace. Her intervention on the arch and adjacent walls revitalizes this transit area and creates exciting chromatic contrasts where the masonry walls of the houses that support the arch produce a vibrant exchange between traditional architecture and modern urban art (Figure 10).

Figure 10. Intervention by Arantxa Recio (Harsa) on the Arch of San Roque (2017). Fuendetodos

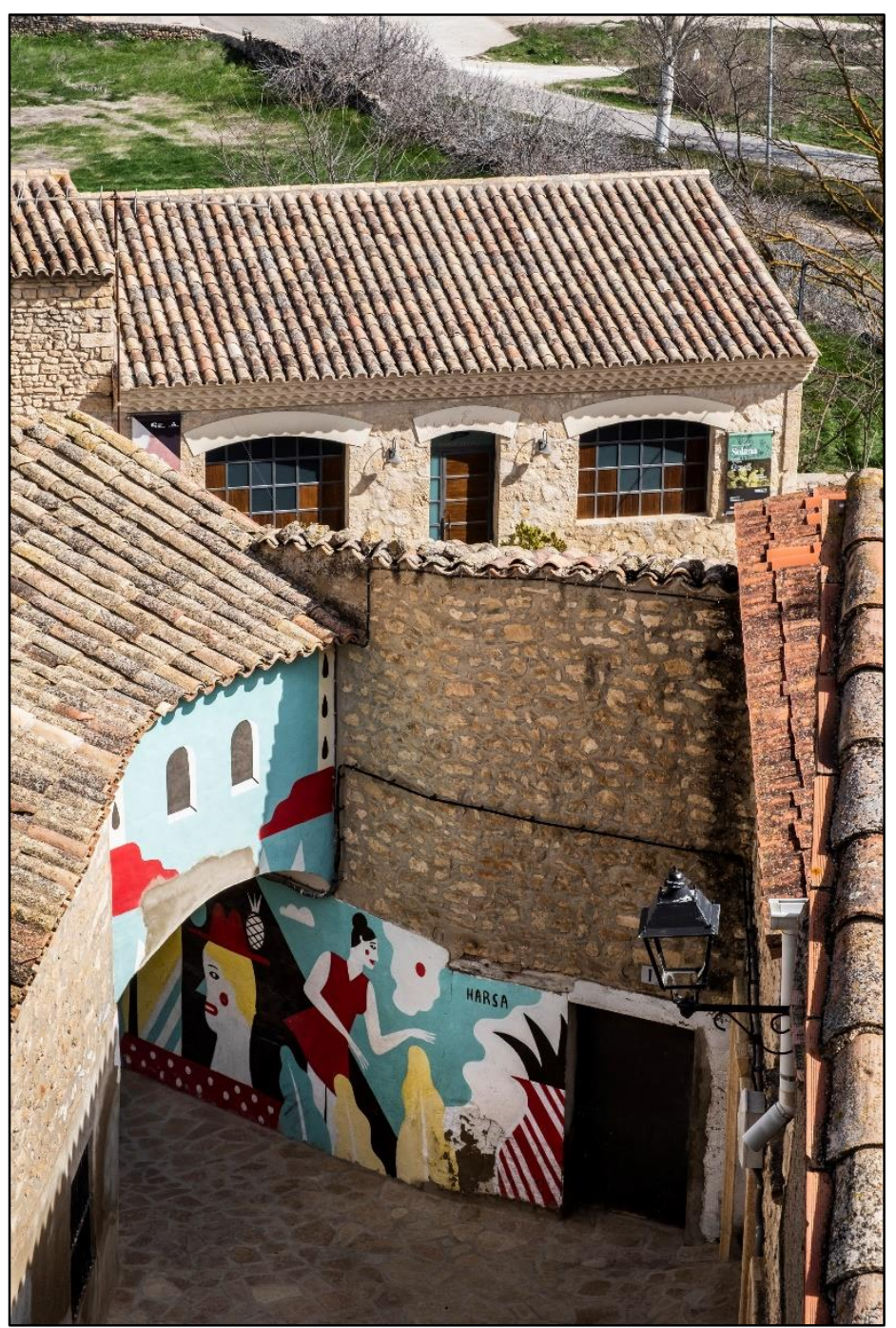

Photograph by the authors of the paper.

Each year in September, on the occasion of the celebration of Goya Week, new murals continue to be created as part of the GSAM initiative. Unlike the expensive unfinished project of the Museum of Contemporary Etching, the creation of an urban art street 
museum has placed art on the walls of the village and fulfilled one the main goals of the initiative undertaken in 2017 by Natalia García, head of the Department of Tourism and Commerce at the Chamber of Commerce of Zaragoza: "we want visitors to see the facades, they needn't walk into a museum to see paintings, Goya's revisited artwork may be admired differently in the streets" (Anonymous, 2017).

\section{DISCUSSION}

Based on the data compiled by our research work, the questions posed are next addressed. Firstly, we analysed the complex process of creation of the artworks that shape the collection of public art in Fuendetodos, from the initiatives of Ignacio Zuloaga and his group of friends in the early 20th century to the latest murals painted by contemporary artists. The creation of all these artworks were in response to the resolve to pay tribute to Francisco de Goya at a particularly crucial moment in disseminating his artwork. Nonetheless, some of the initiatives undertaken by Zuloaga, the SIPA or the recently created Goya Street Art Museum also aim at improving the village's infrastructure and contribute to beautifying the image of the streets and bring contemporary art to locals and tourists. The promotion of Goya has thus served to revitalize the village and might even have a deeper impact in the future.

The second question may also be answered based on the compiled data. The cultural identity of the village is closely linked to the figure of Goya. As a matter of fact, almost all the contemporary public artworks created in Fuendetodos constitute tributes to the painter. This might imply that other forms of cultural expression such as local traditional architecture, the quarries used since the Roman period or the vestiges of the Civil War in nearby Belchite may not have been sufficiently promoted and disseminated.

Thirdly, it should be pointed out that the ensemble of art in this area may serve to revitalize it. As professor Jesús Pedro Lorente pointed out in his book Arte público en Aragón (2016), these artworks may be freely visited by anyone at any time. They therefore act as a lure to attract visitors to contemporary art in a rural environment full of charm and appeal. However, none of the two webpages that publicize Fuendetodos' cultural heritage - the Town Hall and the Foundation Fuendetodos Goya webpages - 9 refer to the rich collection of public art to be found within the village. The lack of information may have possibly resulted in unawareness amongst locals and tourists of this heritage, which so far has not been catalogued by the local corporation, and is liable to disappear as some of the creations, such as Ricardo Calero's Espacios para el deseo are privately owned and their presence in the public space is challenged. The first step to prevent the disappearance of this ensemble involves research. For this reason, the history of the artworks needs to be recorded in writing. At a later stage, they should be compiled in online public art catalogues such as those published by Zaragoza City Hall, created under the scientific direction of art historians (Lorente, 2009).

As new forms of access to cultural heritage are urgently demanded by society some projects carried out by various research groups at the University of Zaragoza have

\footnotetext{
${ }^{9}$ The webpage of Fuendetodos Town Hall does provide information about the graffiti of the Goya Street Art Museum: http://ayuntamientofuendetodos.es/goya-street-art-museum/ (20/11/2021) though it basically consists of photographs of the murals organized by years, without a proper cataloguing. The webpage of the Fundación Fuendetodos Goya includes information about Goya's house of birth, the exhibition hall and the museum of etching, see: https://fundacionfuendetodosgoya.org/ (20/11/2021).
} 
developed the application Aragón Open Air Museum which compiles not only archaeological heritage items but also urban artworks in Aragon (Juberías and Ruiz, 2021). Incorporating the artworks referred to in this paper could contribute to revitalizing them and to improving access to them particularly under the current circumstances of limited travel options.

Finally, the initiatives implemented in Fuendetodos could be linked to those of other small localities throughout Spain in a bid to promote contemporary art. In the past, this was the case of Hecho, a village in the province of Huesca, whose sculpture gatherings were analysed by Prieto and Ruiz (2021). Closer in time is the case of Genalguacil, in the province of Málaga, a village particularly hit by the rural exodus towards the large tourist resorts on the Costa del Sol. The project "Genalguacil Pueblo Museo" has attracted top art gatherings since 1994 which have produced a rich collection of contemporary art in the village. Casado and García (2020) studied the initiatives carried out in this town and, as in the case of Fuendetodos, point out that the involvement of the local population in cultural activities is key to their success as a motor for rural growth.

\section{CONCLUSION}

For over a century, the streets of Fuendetodos have welcomed a variety of urban artworks resulting from different initiatives, actions and projects staged in a village that silently witnessed the gradual decline in the population. Sculpture pedestals and plinths, fallow fields or the walls of old buildings served to display the artistic creations which bring a breath of fresh air to a gradually decaying town. These artworks, which interact differently with visitors, share the identity of a community that has managed to preserve the spirit of its past through striking public art closely linked to Goya's memory.

Local museums in Aragon are accustomed to economic restrictions and lack of funding to support their initial steps, maintenance and future management. The absence of institutional support prevented the initially enthusiastic project of a Museum of Contemporary Etching to come to fruition. Instead, its construction has been on hold since 2014 and its skeleton languishes by the access road to Fuendetodos (Paniagua, 2021). Conversely, cultural projects that incorporate people's involvement last longer in time and draw the proactive support of the local population. Initiatives are being presented to promote local development which may receive external support while optimizing social cohesion in the area of Campo de Belchite. The various instances of public art in Fuendetodos are a precise and clear example of this endeavour. The streets of the village act as a museum for its collection of artworks in the open air to be contemplated by the local inhabitants and by visitors attracted to this cultural enclave and its territory.

The most relevant social agents who possess deep knowledge of the region and its circumstances must get involved in order to encourage active participation that engages and interacts with visitors and facilitates participation in availing of the cultural heritage. In Fuendetodos public art has unquestionably revitalized not only the village itself but its surroundings, in the area known as Campo de Belchite. The memory of Goya continues to grow in the rural sphere through the concept of belonging to a place. These values should be fostered so as to achieve sustainable tourist growth that may reverse the current demographic trend. 


\section{FUNDING AND ACKNOWLEDGMENTS}

This analysis is part of the line of work followed by its authors as members of the investigation team of the Observatorio de Arte Aragonés en la Esfera Pública, funded by the Government of Aragon through FEDER funding and directed by professor Jesús Pedro Lorente Lorente, of the Department of the History of Art of the University of Zaragoza. The research was also funded by a Contribution to Investigation granted by the Instituto de Patrimonio y Humanidades 2020 for the line "El patrimonio cultural, una herramienta contra la despoblación", "Cultural heritage, a tool against depopulation".

The authors wish to express their sincere gratitude to professor Jesús Pedro Lorente for his helpful guidelines, valuable bibliography and generous assistance.

\section{REFERENCES}

Anonymous (9 October 1917). De arte. El homenaje a Goya en Fuendetodos. La Correspondencia de España.

Anonymous (7 October 1917). La Acción. Diario de la Noche.

Anonymous (20 October 1920). En Zaragoza. Inauguración del monumento a Goya. El Imparcial.

Anonymus (14 May 1925). Homenaje a Goya. La Libertad.

Anonymous (7 November 2017). Fuendetodos se transforma en un museo al aire libre dedicado a Goya. El Periódico de Aragón.

Bozal, V. (2020). Otra España Negra. Prensas de la Universidad de Zaragoza.

Camarero, L., and Oliva, J. (2019). Thinking in rural gap: mobility and social inequalities. Palgrave Commun, 5(95). https://doi.org/10.1057/s41599-019-0306-X

Casado, C., and García, M. (2020). Genalguacil, el museo habitado. Diferents. Revista de museus, (5), 110-127. http://dx.doi.org/10.6035/Diferents.2020.5.7

Castán, A. (2016). Señas de identidad, Institución Fernando el Católico.

Correa, E. (30 June 1920). Artistas españoles: Enrique Lorenzo Salazar. La Ilustración Española y Americana.

Cruz, J. (14 November 2019). Goya ya no tiene ni cabras en Fuendetodos. El País. Recuperado

de: https://elpais.com/cultura/2019/09/13/actualidad/1568394782_229154.html

Escar, M. (November 1926). Apuntes de Aragón. La Gaceta de las Artes Gráficas.

Escribano, J. (2012). El valor de los servicios educativos y sanitarios en los procesos de atracción y mantenimiento de población en medio rural. AGER, Revista de Estudios sobre Despoblación y Desarrollo Rural, (13), 11-51. DOI: 10.4422/ager.2011.07.

Escribano, J., and Vercher, N. (2018). Jóvenes y medio rural: ¿un binomio hacia la exclusión?. In V. Paül, R. C. Lois, J. M. Trillo, and F. Haslam (eds.), Infinite rural systems in a finite planet: bridging gaps towards sustainability (pp. 387-394). Santiago: Cursos e Congresos. Universidad de Santiago de Compostela Publicatións. 
Recuperado de: https://www.usc.gal/libros/es/ciencias_sociales_y_jurdicas/495infinite-rural-systems-in-a-finite-planet-.html (30/11/2021).

Fernández, A. (19 February 1989). Igael Tumarkin. Una escultura roja en un cruce de caminos de Pozoblanco. El País.

García de Carpi, L. (1985). Julio Antonio: Monumentos y Proyectos. Fundación Universitaria Española.

García, M. (30 March 2021). 275 Aniversario de Goya. Heraldo de Aragón.

Del Molino, S. (2016). La España vacía. Turner Noema.

Del Molino, S. (2021). Contra la España vacía. Alfaguara.

De la Calle, R. (2013). Dos aproximaciones a la expresividad del hierro en la escultura de José Gonzalvo (1929-2010). Archivo de Arte Valenciano (XCIV), 281-296.

De Lecea, I., Fabre, J., Grandas, C., Huertas, J. M., Remesar, A., and Sobrequés, J. (2009). Art públic de Barcelona. Ayuntamiento de Barcelona and Àmbit Serveis Editorials.

Juan, N., Juberías, G., and Lorente, J. P. (2021). Construyendo el territorio desde la cultura. Nuevas visiones sobre el patrimonio en áreas poco pobladas. Huesca, Instituto de Estudios Altoaragoneses.

Juberías, G., and Ruiz, L. (2021). Difundiendo el arte en el espacio público: “Aragón Open Air Museum”. In E. Andrés, P. Anía, I. Escudero, D. M. Espada, G. Juberías, J. Martín, L. Ruiz, and A. M. Sanz, (eds.), La Historia del Arte desde Aragón. IV Jornadas de Investigadores Predoctorales (pp. 390-391). Prensas de la Universidad de Zaragoza.

Lorente, J. P. (2008). El arte público en las páginas web de los ayuntamientos españoles. In M. Cabañas, A. López-Yarto, and W. Rincón (eds.), Arte, poder y sociedad en la España de los siglos XV a XX (pp. 669-710). CSIC.

Lorente, J. P. (2009). Hacia un museo virtual de arte público en Aragón. In C. Lomba, and C. Giménez (eds.), El arte del siglo XX. Actas del XII Coloquio de Arte Aragonés (pp. 451-464). IFC-DGA.

Lozano, J. C. (2008). La memoria de Goya en Aragón (1828-1978), a golpe de efemérides. In J. C. Lozano, (coord.), La memoria de Goya (1828-1978) (pp. 47-135). Gobierno de Aragón. Departamento de Educación, Cultura y Deporte.

Luque, M., and Pellejero, C. (2009). La promoción turística privada en la España del primer tercio del siglo XX: los Sindicatos de Iniciativa y Turismo. Investigaciones de Historia Económica (15), 38-46. https://doi.org/10.1016/j.ihe.2017.10.001

Marín, M. (April 1928). A Goya, en el primer centenario de su muerte. Aragón.

Mena, M. (2015). Goya y Zaragoza (1746-1775). Sus raíces aragonesas. Fundación Goya en Aragón, Ibercaja y Gobierno de Aragón.

Ostalé, E. (31 December 1925). Ante un centenario. La Hormiga de Oro.

Ostalé, E. (20 April 1928). Cuna de D. Francisco de Goya. Heraldo de Madrid.

Paniagua, S. (28 February 2021). Una ballena varada en Fuendetodos. Heraldo de Aragón.

Prieto, J., and Ruiz, V. (2021). Encuentros de escultores en el valle de Hecho (Huesca) 19891991. In N. Juan, G. Juberías, and J. P. Lorente (eds.), Construyendo el territorio desde la cultura. Nuevas visiones sobre el patrimonio en áreas poco pobladas (pp. 175-190). Instituto de Estudios Altoaragoneses, Diputación Provincial de Huesca. 
Remesar, A. (2007). Arte público en los procesos de regeneración urbana. Exit Book (7), 3440.

Romero, L. y Escribano, J. (2013). Diagnóstico y propuestas para la revitalización de las Sierras de Teruel (Gúdar-Javalambre y Maestrazgo). AGER, Revista de Estudios sobre Despoblación y Desarrollo Rural, (15), 115-152. DOI: 10.4422/ager.2013.01.

Sáez, L. A. (2003). Economía y despoblación: interpretaciones políticas. In S. Escolano, and J. R. De la Riva (coords.), Despoblación y ordenación del territorio (pp. 125-134), Diputación de Zaragoza, Institución Fernando el Católico.

Sáez, L. A., Ayuda, M. I., and Pinilla, V. (2003). La despoblación en Aragón: análisis y políticas. In F. García (coord), La lucha contra la despoblación todavía necesaria: políticas y estrategias sobre la despoblación de las áreas rurales en el siglo XXI (pp. 43-104). Centro de Estudios sobre la Despoblación y Desarrollo de Áreas Rurales.

Sáez, L. A. (2019a). Despoblación y patrimonio cultural inmaterial. In C. Martínez, y V. M. Lacambra (coords.), Actas de la octava Jornada sobre Patrimonio Cultural Inmaterial de la Sierra de Albarracín (pp. 101-110). Comarca de la Sierra de Albarracín.

Sáez, L. A. (2019b). Despoblación, desarrollo y cultura: triángulo cómplice. PH: Boletín del Instituto Andaluz del Patrimonio Histórico, (98), 70-87. https://doi.org/10.33349/2019.98.4511

Salcedo, A. (1997) Julio Antonio, 1889-1919, escultor. Tarragona, Diputació de Tarragona, Museu d'Art Modern.

Senserrich-Espuñes, R., and García, E. (2019). Museos de arte urbano. Estado de la cuestión. G-Conservación, (16), 244-254. https://doi.org/10.37558/gec.v16i0.713

Suárez-Zuloaga, I. (2020). Más de un siglo de cuestión Zuloaga. In I. Suárez-Zuloaga (ed.), El verdadero Ignacio Zuloaga (pp. 71-87). Fundación Zuloaga.

Valenzuela, J. (November 1925). Francisco Goya y Lucientes. Aragón. 
CONTRIBUTION BY AUTHORS

\begin{tabular}{|c|l|c|c|}
\hline & \multicolumn{1}{|c|}{ ITEM } & Guillermo Juberías García & Natalia Juan García \\
\hline 1 & Conceptualization & $60 \%$ & $40 \%$ \\
\hline 2 & Data curation & $60 \%$ & $40 \%$ \\
\hline 3 & Formal analysis & $40 \%$ & $60 \%$ \\
\hline 4 & Funding acquisition & $50 \%$ & $50 \%$ \\
\hline 5 & Investigation & $60 \%$ & $40 \%$ \\
\hline 6 & Methodolgy & $50 \%$ & $50 \%$ \\
\hline 7 & Project administration & $30 \%$ & $70 \%$ \\
\hline 8 & Resources & $60 \%$ & $40 \%$ \\
\hline 9 & Software & $60 \%$ & $40 \%$ \\
\hline 10 & Supervision & $30 \%$ & $70 \%$ \\
\hline 11 & Validation & $40 \%$ & $60 \%$ \\
\hline 12 & Visualiaction & $50 \%$ & $50 \%$ \\
\hline 13 & Writing (original draft) & $60 \%$ & $40 \%$ \\
\hline 14 & Writind (review and editing) & $40 \%$ & $60 \%$ \\
\hline
\end{tabular}

For More information, visit CRediT: https://casrai.org/credit/ 